\title{
Association Vitamin D Receptor (TaqI) Gene Polymorphism with Anthropometric Parameters and Blood Pressure of College Students in Faculty of Medicine, University of Sumatera Utara
}

\author{
Mutiara Indah Sari \\ Departement of Biochemistry, Faculty of Medicine, University of Sumatera Utara, Indonesia \\ muti_dr@yahoo.com
}

\begin{abstract}
Epidemiological studies suggest several genes from the vitamin $D$ receptor have been implicated in obesity and cardiovascular disease. However, the findings were inconsistent.

The aim of this study was to evaluate TaqI polymorphism of the vitamin $D$ receptor (VDR) gene are associated with anthropometric parameters and blood pressure on college students in Faculty of Medicine, Sumatera Utara University.

This was a cross-sectional study. Measurements of anthropometric parameters were carried out. Blood pressure measurement using a mercury sphygmomanometer. TaqI polymorphiss of VDR gene were geno- typed by PCR and FRLP. Statistical analysis were calculated using SPPS software (version 14.0).

The prevalence of TaqI genotypes were $117(84 \%)$ TT and 22 $(16 \%)$ Tt. Homozygous tt was not found in the subjects. There were no significant differences in anthropometric parameters (BMI and WHR) and blood pressure between TaqI polymorphism of the VDR gene $(p=0.321 ; p=0.607 ; p=0.278)$

The results suggest that TaqI VDR polymorphism are not related with the obesity and not risk factor of cardiovascular disease on college students in Faculty of Medicine, University of Sumatera Utara
\end{abstract}

Keywords- TaqI VDR polymorphism, anthropometric parameters, blood pressure

\section{INTRODUCTION}

It has been argued that vitamin D deficiency as a global health issue may contribute to the pathogenesis of obesity, cardiovascular disease (CVD), the metabolic syndrome and type 2 diabetes [1].

Clinical and epidemiological studies show that obese individuals tend to have low vitamin D status [2]. The present data are in accordance with Lender et [3] have also reported a relationship between vitamin $\mathrm{D}$ status of someone with body fat distribution. Vitamin D increases calcium absorption through the intestine and reduce the excretion of calcium through the kidneysSo, Vitamin D is very important to maintain calcium balance. Low calcium increases kalsitropik hormone and parathyroid hormone synthesis.

Parathyroid hormone in the body can improve the process of lipogenesis (fat synthesis), inhibits lipolysis (fat degradation) and modulate adipogenesis. Adipogenesis process is the process of morphological changes, cell development, and accumulation of fat [4].

Calcium with vitamin D is known to suppress appetite, extend the distance between meals and reduce food intake the next day [5].

Research on teenagers in Korea found a significant negative correlation between serum 25 hydroxyvitamin D levels and body mass index (BMI) [6]. Fish et al [7] reported a significant correlation between serum vitamin D levels and obesity

Low vitamin D levels were also associated with an increased prevalence of hypertension, high sistolic blood pressure (SBP) and diastolic blood pressure (DBP). Clinical studies demonstrated an inverse, dose-response relationship between plasma $1,25(\mathrm{OH}) 2 \mathrm{D} 3$ concentration and blood pressure or renin activity in both normotensive and hypertensive patients [8], [9].

Vitamin D activity mediated by vitamin D receptor (VDR). Some research suggests that the VDR gene polymorphism may be a genetic and genotype component that affect the degree or VDR function. VDR polymorphisms will reduce the activity of vitamin D.

Studies have found associations between vitamin D pathway gene polymorphisms and circulating 25(OH) D level [10], [11]. 
Santos et al showed [12] association with lower vitamin D levels, suggesting that VDR gene polymorphisms could be linked to higher susceptibility to vitamin D deficiency

This is the underlying pathogenesis of the onset of disorders such as obesity, cardiovascular disease and other diseases associated with a polymorphism of the VDR gene.Thus VDR gene polymorphisms may correlate with different diseases.

Al-Daghri et al [13] showed associations of vitamin D receptor gene polymorphisms with obesity. Similarly Hajj el al [14] reported relationship between vitamin $\mathrm{D}$ receptor gene polymorphisms with BMI and waist circuference (WC) in in a healthy young population. Wang et al [15] reported associations of hypertension risk and plasma 25-hydroxyvitamin D and vitaminD receptor polymorphism

Even though, association studies of genetic variants in vitamin $D$ pathway genes with obesity and blood pressure are limited and inconsistent [16], [17], [18].

The aim of this study was to evaluate Taq1 polymorphisms of the vitamin $\mathrm{D}$ receptor (VDR) gene are associated with anthropometric parameters, BMI and waist hip ratio (WHR) and blood pressure on college students in Faculty of Medicine, University of Sumatera Utara

\section{METHODS}

This study was a cross sectional study, conducted at the Integrated Laboratory of the Faculty of Medicine, University of Sumatera Utara. This study was conducted after obtaining approval from the Ethics Commission. The subjects were students of the Faculty of Medicine, University of Sumatera Utara in 2016, and aged 16-23 years. They were asked to fill out and sign an informed consent after being given an explanation about the purpose and benefits of the research.

Anthropometric measurements of body mass and body height were made, both measured on subjects without top clothing and shoes. BMI as body mass divided by the square of height $(\mathrm{kg} / \mathrm{m} 2)$. We used body mass index $(\mathrm{BMI})>25 \mathrm{~kg} / \mathrm{m}^{2}$ or $\mathrm{BMI}>95^{\text {th }}$ percentile (according to age and sex of Centre for Disease Control/ CDC Growth Chart) to estimate obesity. WC was measured to the nearest $0.1 \mathrm{~cm}$ over the unclothed abdomen at the smallest diameter between the costal margin and the iliac crest (the hip), at the end of a normal expiration. WHR was calculated by dividing the WC by that of the hip

Systolic Blood Pressure (SBP) and diastolic Blood Pressure (DBP) were measured in seated subjects aftera rest for at least $15 \mathrm{~min}$ using a mercury tensiometer.

Genomic DNA was extracted from peripheral blood leukocytes. ApoA5 polymorphism genotyping is done by polymerase chain reaction-restriction fragment length polymorphism (PCR-RFLP). PCR product using Primer Forward in Intron 8: 5'- AGA GCA TGG ACA GGG AGC AAG-3' and Reverse in Exon 9: 5'-GCA ACT CCT CAT GGC TGA GGT CTC A-3'. PCR conditions were as follows: denaturation at $94^{\circ} \mathrm{C}$ for $5 \mathrm{~min}$, followed by 40 cycles of PCR at $94^{\circ} \mathrm{C}(30 \mathrm{sec}), 61^{\circ} \mathrm{C}(30 \mathrm{sec})$, and $72^{\circ} \mathrm{C}(30$ $\mathrm{sec})$. Identified by ethidium bromide staining of fragments separated in a 2\% agarose gel. Result: 745 bp spanning Taq1 site

Amplicon digestion then was done using TaqI restriction enzyme. Enzyme digestion reaction was completed with $17 \mu \mathrm{l}$ water, $2 \mu \mathrm{l} 10 \mathrm{X}$ Fast digestGreen buffer, $10 \mu \mathrm{l}$ PCR product and $1 \mu \mathrm{l}$ enzyme, incubated at $65^{\circ} \mathrm{C}$ for $2 \mathrm{~h}$. The digested DNA with taq1 resulted in three fragments of 293 , 251 and $201 \mathrm{bp}$ in presence of taq1 polymorphic site, and in fragments of $496 \mathrm{bp}$ and $249 \mathrm{bp}$ in its absence, visualized using $2 \%$ agarose gel using gel documentation system. The polymorphism are presented as $\mathrm{TT}, \mathrm{Tt}$ and $\mathrm{tt}$.

All the data were obtained, clustered and statistically analyzed analyzed univariately, and bivariately use SPSS program version 14

\section{RESULTS AND DISCUSSION}

TABLE I

CHARACTERISTICS OF THE STUDIED SUBJECT

\begin{tabular}{|l|l|l|}
\hline Anthropometry & & \\
Body Weight $(\mathrm{kg})$ & $69.91 \pm 20.27$ & $40 ; 133$ \\
Height $(\mathrm{cm})$ & $162 \pm 10.10$ & $97 ; 186$ \\
BMI $\left(\mathrm{kg} / \mathrm{m}^{2}\right)$ & $26.26 \pm 5.81$ & $16.41 ; 44.37$ \\
Waist circumference $(\mathrm{cm})$ & $87.38 \pm 14.11$ & $61 ; 126$ \\
Hip circumference $(\mathrm{cm})$ & $96.64 \pm 12.60$ & $69 ; 132$ \\
\hline WHR & & \\
Normal $\mathrm{n}(\%)$ & $38(27)$ & \\
High $\mathrm{n}(\%)$ & $101(73)$ & \\
Obese $\mathrm{n}(\%)$ & $75(54)$ & \\
Non Obese $\mathrm{n}(\%)$ & $64(46)$ & \\
\hline
\end{tabular}




\begin{tabular}{|l|l|l|}
\hline Blood Pressure & $111.22 \pm 11.11$ & $80 ; 140$ \\
SBP $(\mathrm{mmHg})$ & $74.69 \pm 9.08$ & $50 ; 100$ \\
DBP $(\mathrm{mmHg})$ & $6(4)$ & \\
Normal n(\%) & $133(96)$ & \\
High n(\%) & & \\
\hline Taq1 VDR & $117(84)$ & \\
TT n (\%) & $22(16)$ & \\
Tt n $(\%)$ & & \\
\hline
\end{tabular}

In this study obtained 117 subjects with the variant Taq1 TT (84\%) and $22(16 \%)$ subjects with Tt. Homozygous tt was not found in the subjects. The polymorphism of this study population were consistent with the results of populations of China [19] and Thailand [20], were also not found the tt genotype in their study population the different results were found in the population in the American Countries. In Mexican was found tt and Tt genotype frequencies more than TT genotype there are several [21]. Research conducted by Haddad [22] showed in Syrian population was found $\mathrm{Tt}$ genotype frequencies more than TT genotype but tt genotype less than TT and tt genotypes

Polymorphisms have been identified in VDR gene, mostly identified by variation bialel on enzymes restriction method Restriction fragment length polimorphisms (RFLPs), one of them is the VDR gene TaqI polymorphism. Taq1 RFLPs lies between exon 8 and 9 consist of TT, TC and CC, presented as $\mathrm{TT}, \mathrm{Tt}$ and tt. [23]. VDR gene polymorphism in population arises from the differences between genotypes and alleles according to the ethnicity. These effects could be occurred by the differences in race and diet [22]

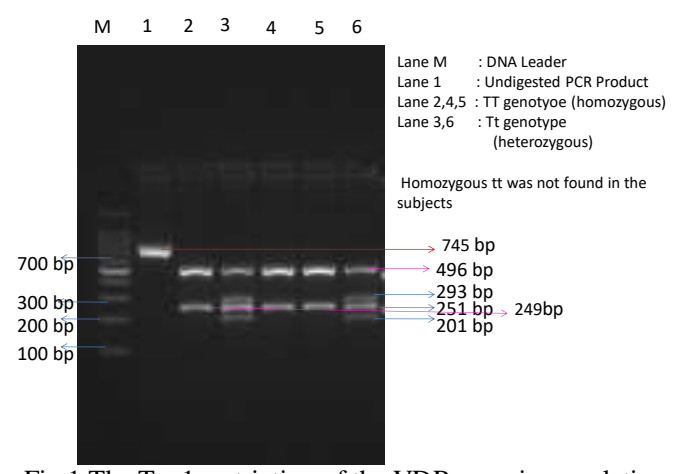

Fiq 1.The Taq1 restriction of the VDR gene in population

Genotype frequencies of VDR Taq1 gene polymorphism and their association in anthropometric parameters and blood pressure are displayed in table 2.
TABLE II

ASSOCIATION VDR TAQ1 GENOTYPE WITH ANTHROPOMETRIC PARAMETERS AND BLOOD PRESSURE

\begin{tabular}{|l|l|l|l|l|}
\hline & \multicolumn{2}{|l|}{ Genotype } & $\mathrm{p}$ & OR (95\% CI) \\
\hline & $\mathrm{TT}$ & $\mathrm{Tt}$ & & \\
\hline BMI & & & & \\
\hline $\begin{array}{l}\text { Non obese } \\
\text { Obese }\end{array}$ & 56 & 8 & 0.321 & $1.60(0.62-4.11)$ \\
\hline $\begin{array}{l}\text { WHR } \\
\text { Normal } \\
\text { High }\end{array}$ & 31 & 7 & 0.607 & $0.77(0.28-2.07)$ \\
\hline $\begin{array}{l}\text { BP } \\
\text { Non } \\
\text { hypertension } \\
\text { Hypertension }\end{array}$ & 66 & 15 & & \\
\hline
\end{tabular}

Based on the chi square test is found no association between VDR Taq1 gene polymorphism with BMI. The prevalence of TaqI genotypes were $87 \% \mathrm{TT}, 13 \% \mathrm{Tt}$, in non obese subject, and $81 \%$ TT, $19 \% \mathrm{Tt}$, in obese subject (TT vs Tt, $p=0.321$, OR $1.60,95 \%$ CI $0.62-4.11$ ) (Table 2). In this study also showed no association between VDR Taq1 gene polymorphism with WHR and BP. The prevalence of TaqI genotypes were $87 \% \mathrm{TT}, 13 \% \mathrm{Tt}$, in normal WHR subject, and $82 \% \mathrm{TT}, 18 \% \mathrm{Tt}$, in high WHR (TT vs Tt, $p=0.607$, OR 0.77, 95\% CI 0.28-2.07) and $83 \% \mathrm{TT}, 17 \% \mathrm{Tt}$, in non hypertension subject, and $100 \%$ TT, in hypertension (TT vs Tt $P=0.278$ )

The results are consistent with research from Bid et [24] which states no association between VDR Taq1 gene polymorphism with BMI, SBP and DBP in type 2 of diabetes mellitus in north Indians. Research conducted by Hajjet all [14] in young Lebanese women was found no association between VDR Taq1 gene polymorphism with WHR and BP. BM, WC, SBP and DBP. The different results were found in the group of young Lebanese Men. In this group was showed no relationship between VDR Taq1 gene polymorphism with BMI and WC but not with SBP and DBP

Vitamin D is a generic name of two molecules, ie ergocalciferol (vitamin D2) and cholecalciferol (vitamin D3). Precursors of vitamin D is present in a fraction of sterol in animal tissue (under the skin) and herbs in the form of 7-dehydrocholesterol and ergosterol. Both require ultraviolet radiation to convert it into a form of provitamin D3 (cholecalciferol) and D2 (ergocalciferol). Both 
provitamin require conversion to the active form by adding the two groups hydroxyl [25].

The action of $1,25(\mathrm{OH}) 2 \mathrm{D} 3$ is mediated through the VDR, a member of the nuclear receptor superfamily, which regulates the transcription of many target gene. The VDR gene is distributed on chromosome 12q12-q14. Eight exons and six alternatively spliced regions (1a-1f) are located in functionally relevant areas, including the promoter region [23], [26].

Recent studies have indicated many polymorphisms to exist in the vitamin $\mathrm{D}$ receptor (VDR) gene, but the influence of VDR gene polymorphisms on VDR protein function and signaling is largely unknown. Polymorphisms are variations DNA sequences that cause genetic diversity in the gene pool of a population. The amino acid sequence protein is determined by information contained in the genes compiled by DNA. Genes that have the sequence Different considered polymorphic. [23], [26]

Polymorphisms are formed through a process of mutation that can occur because of the substitution, deletions or insertions in the polynucleotide sequence. Polymorphisms have a neutral effect on biological function. However, in some circumstances may cause a disturbance biological functions. This happens because there is a change in the composition of DNA that encodes the protein. Polymorphisms can also be found in the area of DNA do not code for proteins [23], [26].

The TaqI polymorphism are located at the 3' untranslated region ( $3^{\prime}$ UTR) of the VDR gene. It is a silent SNP in exon 9. Although 3' UTR has been recognized as a region involved in the modulation of gene expression, especially through the regulation of mRNA stability and efficiency of protein translation, the functional role of the TaqI VDR gene polymorphisms has not been established. As it has been suggested that the TaqI polymorphism is a silent mutation, it results in no amino acid sequence change [22]. This evidence may partly explain the result of this study.

\section{CONCLUSIONS}

The results suggest that Taq1 VDR polymorphisms are not related with the obesity and not risk factor of cardiovasculer disease on college students in Faculty of Medicine, University of Sumatera Utara. Further experimental and translational studies are needed to unravel the signalling role of vitamin $\mathrm{D}$ in adipose tissue, particularly its putative link to adipocyte dysfunction in obesity.

\section{REFERENCES}

[1] Osei K. 25-OH vitamin D: is it the universal panacea for metabolic syndrome and type 2 diabetes? J Clin Endocrinol Metab 95, 42204222. 2010

[2] JI Botella-Carretero, F Alvarez-Blasco, JJ Villafruela, et al. Vitamin D deficiency is associated with the metabolic syndrome in morbid obesity. Clin Nutr 26, 573-580. 2007

[3] Lenders, Carine . Relation of body mass indexes to vitamin D status and deficiency among obese adolescents. The American Journal of Clinical Nutrition. Vol.90: 459-67.2009

[4] McCarty MF, Thomas CA. PTH excess may promote weight gain by impeding catecholamine-induced lipolysis-implications for the impact of calcium, vitamin D, and alcohol on body weight. Med Hypotheses 61:535-542. 2003

[5] Rosenblum, Jennifer L.. Calcium dan vitamin D supplementation is associated with decreased abdominal visceral adipose tissue in overweight and obese adult. The American Journal of Clinical Nutrition. Vol.95: 101-8.2012

[6] Nam Ga Eun, Kim Do Hoon, Kyung Hwan Cho, Yong Gyu Park, Kyung Do Han,Youn Seon Choi, et al. Estimate of a predictive cut-off value for serum 25 hydroxyvitamin $D$ reflecting abdominal obesity in Korean adolescents. Nutr Res;32:395-402. 2012

[7] Fish E, Beverstein G, Olson D, et al. Vitamin D status of morbidly obese bariatric surgery patients. J Surg Res 164, 198-202. 2010

[8] N. Aggarwal, J. P. Reis, and E. D.Michos, "Vitamin D deficiency and its implications on cardiovascular disease," Current Cardiovascular Risk Reports, vol. 4, no. 1, pp. 68-75, 2010.

[9] S. U. Nigwekar and R. Thadhani, "Vitamin D receptor activation: Cardiovascular and renal implications," Kidney International Supplements, vol. 3, no. 5, pp. 427-430, 2013.

[10] Ahn J, Yu K, Stolzenberg-Solomon R, Simon KC, McCullough ML, Gallicchio L et al. Genome-wide association study of circulating vitamin D levels. Hum Mol Genet ; 19: 2739 -- 2745. 2010

[11] Wang TJ, Zhang F, Richards JB, Kestenbaum B, van Meurs JB, Berry $\mathrm{D}$ et al. Common genetic determinants of vitamin D insufficiency: a genome-wide association study. Lancet; 376: 180 -- 188. 2010

[12] Santos Betânia R, Mascarenhas Luis P G, Satler Fabíola, Boguszewski Margaret C S, Spritzer. Poli Mara Vitamin D deficiency in girls from South Brazil: a cross-sectional study on prevalence and association with vitamin D receptor gene variants. BMC Pediatrics 12:62.2012

[13] Al-Daghri Nasser M., Guerini, Franca R, Al Attas Omar S, Alokail Majed S, Alkharfy Khalid M., Draz Hossam M. Agliardi Cristina, Andrea S. Costa, Irma Saulle, Abdul Khader Mohammed, Mara Biasin, Mario Clerici. Vitamin D Receptor Gene Polymorphisms Are Associated with Obesity and Inflammosome Activity PLoS ONE 9(7). 2014

[14] Hajj Aline, Chedid Rima, Chouery Eliane, Megarbané André, Gannagé-Yared Marie-Hélène. Relationship between vitamin D receptor gene polymorphisms, cardiovascular risk factors and adiponectin in a healthy young population Pharmacogenomics (2016) 17(15), 1675-1686

[15] Wang L, Chu A, Buring JE, Ridker PM, Chasman DI, Sesso HD. Common genetic variations in the vitamin $\mathrm{D}$ pathway in relation to blood pressure. Am. J. Hypertens. 27(11), 1387-1395 (2014).

[16] Reis AF, Hauache OM, Velho G. Vitamin D endocrine system and the genetic susceptibility to diabetes, obesity and vascular disease. A review of evidence. Diabetes Metab 2005; 31: 318 - 325.

[17] Zhao Yi, Liao Sha, He Jun, Jin Yanan, Hailong Fu, Xiaoying, Xuemin Fan, Hongxia Xu, Xiuying Liu, Jing Chen Jin and Yuhong Zhang. Association of vitamin D receptor gene polymorphisms with metabolic syndrome: a case-control design of 
population-based cross-sectional study in North China Lipids in Health and Disease 2014, 13:129

[18] Relationship between Vitamin D Receptor gene polymorphisms and the components of metabolic syndrome Natielen Jacques Schuch, Vivian Cristina Garcia, Sandra Roberta Gouvea Ferreira Vívolo and Lígia Araújo Martini. Nutrition Journal 2013, 12:96

[19] Kung, A.W., Yeung, S.S., Lau, K.S., 1998. Vitamin D receptor gene polymorphisms and peak bone mass in southern Chinese women. Bone 22 (4), 389-393.

[20] Ongphiphadhanakul, B., et al., Vitamin D receptor gene polymorphism is associated with urinary calcium excretion but not with bone mineral density in postmenopausal women. J. Endocrinol. Investig. 20 (10), 592-596. 1997

[21] Sainz, J., et al., 1997. Vitamin D-receptor gene polymorphisms and bone density in prepubertal American girls of Mexican descent. N. Engl. J. Med. 337 (2), 77-82.

[22] Haddad Shaden. Vitamin-D receptor (VDR) gene polymorphisms (Taq-I \& Apa-I) in Syrian healthy population. Meta Gene 2 (2014) 646-650

[23] Uitterlinden, A.G., et al., 2004. Genetics and biology of vitamin D receptor polymorphisms. Gene 338 (2), 143156.

[24] Bid Hemant Kumar, Konwar Rituraj, C. G. Aggarwal, Sunaina Gautam, Madhukar Saxena, V. Lakshma Nayak, Monisha Banerjee.Vitamin D Receptor (Foki, Bsmi And Taqi) Gene Polymorphisms And Type 2 Diabetes Mellitus: A North Indian Study. Indian J Med Sci, Vol. 63, No. 5, May 2009

[25] Ding Cherlyn, Gao Dan, Wilding John, Paul Trayhurn and Chen Bing. Vitamin D and adipose tissue function. British Journal of Nutrition (2012), 108, 1915-1923

[26] Carsten Carlberg, Moray J. Campbell] Vitamin D receptor signaling mechanisms: Integrated actions of a well-defined transcription factor. Steroids 78 (2013) 127-136 